\title{
JUURNAL_RU
}

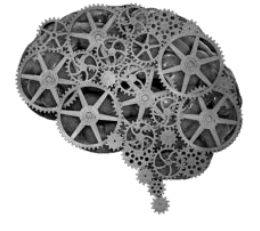

COMPANY GROUP "INTELLEKT"

\author{
Тихонов Е.И. \\ ФГБОУ ВО Дальневосточный ГАУ \\ Благовещенск, Россия
}

doi: 10.18411/lj2016-8-2-12

idsp 000001:lj2016-17-2-12

\section{Сельские территории в системе воспроизводства человеческого капитала аграрной сферы}

Господствующая в условиях плановой экономики модель сельского развития, основанная на доминировании колхозов и совхозов, функционирующих под контролем государства и ориентированных на обеспечение полной занятости всего трудоспособного сельского населения, оказалась не адекватна условиям практически не регулируемой рыночной экономики. Приоритетом аграрной политики нашего государства в области сельского развития в последнее время стало развитие сельских территорий, причем перспективы этого развития связываются, в первую очередь, с диверсификацией сельской экономики, тогда как потенциал аграрного производства представляется далеко не исчерпанным.

В условиях плановой экономики категория «сельские территории» не использовалась, поскольку основными объектами управления сельским развитием являлись колхозы и совхозы, на которые государством были возложены функции экономического и социального развития сельских населенных пунктов, формирования комфортной среды проживания сельского населения, воспроизводства трудовых ресурсов и вовлечения их в процесс общественного производства. Разрушив колхозно-совхозную систему организации аграрного производства и сельского развития, государство долгое время не могло предложить обществу эффективную альтернативу. Резкое падение эффективности сельского хозяйства и катастрофическое сокращение объемов финансирования сельского развития обусловили деформационные 
изменения сельских территорий, повлекшие нарушение структурной и функциональной целостности их экономической и социальной подсистем.

Сельские территории традиционно рассматриваются как среда обитания и жизнедеятельности сельского населения, базовые функции которой были законодательно закреплены в Концепции устойчивого развития сельских территорий Российской Федерации на период до 2020 г., (производственная, демографическая, трудоресурсная, жилищная, пространственнокоммуникационная, социального контроля). Кроме данных функций в современной экономической литературе выделяются также социальная, политическая, культурная, экологическая, рекреационная, организационноуправленческая, информационная функции, функция оказания муниципальных услуг и др. $[4,6,7]$

В соответствии с данной Концепцией к основным целями политики государства в отношении сельского развития относятся: формирование условий, необходимых для реализации сельскими территориями своих функций и задач сельского развития; развитие экономики сельских территорий, рост эффективности и устойчивости сельского хозяйства, доходов сельского населения; создание новых рабочих мест занятости, повышения качества жизни населения сельских территорий, приближение к стандартам жизни городского населения; стабилизация численности населения сельских территорий и увеличение срока жизни; снижение межрегиональных и внутрирегиональных отличий в уровне жизни населения сельских территорий; формирование системы рационального использования природных ресурсов и охрана окружающей среды; развитие культурного и нравственно-духовного потенциала сельских территорий. Но декларация целей и задач сельского развития на уровне государства без адекватной системы мотивации сельского населения и возможностей реализации их экономических интересов обуславливает неэффективность аграрной политики, поскольку не предполагают описания мер, реализация которых может принципиально изменить модель поведения сельских жителей.

При этом следует помнить, что специфика сельского образа жизни напрямую определяется спецификой труда и быта сельских жителей, обусловленной необходимостью подчинения их жизнедеятельности природным 
ритмам и циклам; более тяжелым условиями труда; низким уровнем мобильности; взаимосвязью труда и быта; низким уровнем механизации производственных процессов в хозяйствах населения; ограниченными возможностями выбора занятости; ограниченностью возможностей проведения свободного времени и т.д. [2,5,8]

Нельзя не согласиться с мнением О.В. Нечипоренко и В.В. Самсонова [1], отмечающих, что на фоне деградации технико-технологической базы, деформации организационно-экономического механизма сельского развития, затяжного спада аграрного производства наблюдается сжатие социальной группы, ориентированной на реализацию модели активного экономического поведения. Пассивный тип поведения становится доминирующим практически во всех группа сельского сообщества. Реактивно-пассивная стратегия адаптации сельского населения начала реализовываться через натурализацию домашних хозяйств, проявляющуюся в увеличении уровня самообеспечения сельских жителей жизненно важными необходимыми продуктами питания и вынужденной самозанятости в домашнем хозяйстве). Они справедливо отмечают, что либерально-модернистский подход к решению проблем сельского развития оказался не совсем адекватным инструментом, используемым для оценки влияния всех социальных и экономических факторов, воздействующих на изменение поведения сельского сообщества. В рамках данного подхода практически игнорируется неоднозначность и разновекторность преобразований среды развития, хотя даже в границах муниципальных районов наблюдается колоссальная дифференциация сельских территорий по уровню развития сельского хозяйства, степени интеграции в единое экономическое пространство, качеству жизни сельского населения и т.П. Кроме того, из-за игнорирования социальных изменений, происходящих в аграрной сфере были практически исключены из рассмотрения такие последствия глобального реформирования аграрного сектора, как функциональная трансформация сельских территорий, массовый пересмотр стратегий индивидуального и коллективного поведения, разрушение традиционного сельского уклада жизни, резкое усиление миграционной активности сельского населения.

Дифференциация сельских территорий (по уровню социальноэкономического развития, различия в природно-климатических условиях, 
уровнях интеграции в единое экономическое и информационное пространство, качеству жизни, выгодности географического положения, качеству инвестиционного климата и т.п.) объективно обуславливают выбор индивидуальных траекторий развития сельских территорий. Попытки типологизации сельских территорий позволяют повести систематизацию проблем, ограничивающих возможности сельского развития, но не позволяют выработать универсальные рецепты их разрешения [9].

Исследуя проблему повышения устойчивости развития сельских территорий, П.Е. Подгорбунских и Л.В. Субботина [3], приходят к выводу о необходимости научного обоснования положений, регламентирующих порядок территориальной организации сельского развития. Определяя организацию как внутреннюю упорядоченность и согласованность функционирования отдельных элементов социально-экономической системы в соответствии с ее функциями и структурой, а также как множество процессов, формирующих систему взаимосвязей между этими элементами, они выделяют следующие положения: организация территориального развития является осознанно реализуемым процессом, связанным с достижением заданных параметров системы, обеспечивающих достижение экономических, социальных, экологических и других целей; территориальная организация решает задачи территориального размещения объектов хозяйствования, регламентирует пространственное взаимодействие хозяйствующих субъектов, обосновывая их оптимальные сочетания и комбинации, создавая предпосылки формирования территориальноотраслевых комплексов холдингового или кластерного типов; организация территориального развития предполагает независимость хозяйствующих субъектов в выборе направлений производственной деятельности в соответствии с их экономическими интересами; эффективная территориальная организация ориентирована на развитие системы мотивации ведение экономической деятельности в формах и размерах, максимально соответствующих приоритетам общественного развития; эффективная территориальная организация предусматривает необходимость создания условий непрерывного развития технико-технологической базы, повышения качества человеческого капитала, конкурентной среды, системы разделения и кооперации труда и других факторов, влияющих на деятельность экономических агентов; глобальная цель 
рациональной территориальной организации заключается в формировании пространственной упорядоченности жизнедеятельности сельского сообщества в соответствии с парадигмой развития общества и его отдельных элементов под действием объективных экономических законов.

В современной экономике существует три основные модели сельского развития: отраслевая (драйвером сельское развития выступает развитие аграрного производства), перераспределительная (акцент делается на перераспределении финансовых ресурсов для выравнивания уровня развития сельских и городских территорий) и территориальная (целью сельского развития является развитие сельских территорий). Приоритетом аграрной политики нашего государства в области сельского развития в последнее время стало развитие сельских территорий, причем перспективы этого развития связываются, в первую очередь, с диверсификацией сельской экономики, тогда как потенциал аграрного производства представляется далеко не исчерпанным. При этом следует признать, что технико-технологическая модернизация сельского хозяйства и переход на инновационный путь развития обуславливают существенное сокращение сельскохозяйственной занятости и рост социального напряжения на селе, что требует пересмотра структуры инвестиций в формирование человеческого капитала и формирования среды, обеспечивающей возможности его эффективной реализации. 


\section{Литература:}

1. Нечипоренко, О.В., Самсонов В.В. Векторы развития сельских территорий в условиях глобальных вызовов // Сибирский философский жур-нал. 2014. T.12. №1. C. 108-115.

2. Новиков, В.Г., Чалый, В.С. Трудовой потенциал сельских территорий: специфика предметной рефлексии и характера развития в транзитарный период // Вестник Российского государственного аграрного заочного университета. 2012. №13. С. 159-163.

3. Подгорбунских, П.Е., Субботина, Л.В. Теоретические основы территориальной организации аграрного производства // Вестник Курганской ГСХА. 2012. №3 (3). С. 4-8.

4. Реймер, В.В., Улезько, А.В. Концептуальные и методологические подходы к формированию инновационной системы агропродовольственного комплекса // Вестник Воронежского государственного аграрного университета. 2015. №4 (47). С. 196-207.

5. Реймер, В.В., Улезько, А.В., Тютюников А.А. Инновационноориентированное развитие АПК Дальнего. Воронеж: ВГАУ, 2016. 348 с.

6. Савченко, Т.В., Просянникова, Ю.А, Улезько, А.В. Развитие аграрного потенциала сельских территорий. Воронеж: Научная книга, 2015. 175 с.

7. Третьякова, Л.А. Социально-экономические условия формирования и развития трудового потенциала сельских территорий // Экономический анализ: теория и практика. 2012. №32. С. 2-10.

8. Улезько, А.В., Алексеева, Н.В. Обеспечение конкурентоспособно-сти малых форм хозяйствования. Воронеж: ИПЦ «Научная книга», 2015. 179 с.

9. Улезько, А.В., Реймер, В.В. Условия формирования инновационной модели развития социально-экономических систем // Вестник Воронежского государственного аграрного университета. - 2015. - №2 (45). - C. 84-91. 